Ewa Andrysiak

Uniwersytet Łódzki

\title{
Maszynopis ostatniej pracy Jana Muszkowskiego w zbiorach Ksiązinicy Pedagogicznej im. A. Parczewskiego w Kaliszu
}

\section{Rękopisy w zbiorach Książnicy Pedagogicznej}

Cennym nabytkiem zbiorów specjalnych Książnicy Pedagogicznej im. A. Parczewskiego w Kaliszu jest wprowadzony do nich przed laty autorski maszynopis jednej z prac wybitnego bibliologa Jana Muszkowskiego. Warto omówić ów interesujący dokument stanowiący ciekawy przykład zmodyfikowanej formy rękopisu, jakim od początku ubiegłego stulecia stały się maszynopisy prac, zawierające również ślady odręcznych ingerencji. Dokument ten jest dzisiaj przechowywany w bibliotece funkcjonującej w Kaliszu od 1949 r., najpierw pod nazwą Pedagogiczna Biblioteka Powiatowa, następnie w latach 1975-1998 jako Pedagogiczna Biblioteka Wojewódzka, która w 1994 r. otrzymała imię Alfonsa Parczewskiego, wybitnego kaliszanina, prawnika, działacza politycznego, społecznego i kulturalnego, rektora Uniwersytetu Stefana Batorego w Wilnie. Od 1999 r., po likwidacji województwa kaliskiego, biblioteka przekształcona została w Książnicę Pedagogiczną im. A. Parczewskiego.

Książnica Pedagogiczna jest obecnie jedną z około 330 bibliotek pedagogicznych, działających na terenie kraju. Od początku działalności gromadzi książki i czasopisma, a od 1976 r. zbiory specjalne, które dziś stanowią ważną część zasobu bibliotecznego.

Gromadzenie zbiorów specjalnych rozpoczęło się od mikrofilmów i przezroczy (1976), następnie dołączyły zbiory audiowizualne (filmy, płyty gramo- 
fonowe, taśmy magnetofonowe), kartografia i fotografie (1977). W 1979 r. tematyka zbiorów specjalnych rozszerzyła się, biblioteka zaczęła kompletować starodruki oraz grafikę (w tym ekslibrisy). Dziesięć lat później (1989) zapoczątkowano kolekcję kaset VHS, później dołączyły dokumenty elektroniczne (płyty CD i DVD). Zbiory specjalne Książnicy Pedagogicznej to 3870 jednostek inwentarzowych ${ }^{1}$. Poza tym Książnica Pedagogiczna posiada kolekcje regionalne, dotyczące osób, organizacji i instytucji; są to kolekcje kaliskiego pisarza i poety Eligiusza Kor-Walczaka, artysty grafika Władysława Kościelniaka, Antoniny i Oskara Meysztowiczów, obejmująca zbiory związane z Alfonsem Parczewskim, Technikum Budowy Fortepianów w Kaliszu. W opracowaniu są kolekcje Kaliskiego Oddziału Towarzystwa Przyjaciół Książki 1977-2002, Anny i Ryszarda Templewiczów, obejmująca przede wszystkim wydawnictwa Kaliskiej Drukarni Akcydensowej oraz kolekcja Technikum Ekonomicznego w Kaliszu.

Grupa, gromadzonych od 1991 r., rękopisów na koniec 2013 r. liczyła 96 jednostek inwentarzowych, które do zbiorów biblioteki trafiły zarówno w formie zakupu, jak i darów.

W zespole rękopisów można wyodrębnić dokumenty rękopiśmienne z XIX i początków wieku XX oraz pojedyncze manuskrypty (w części maszynopisy) z naniesionymi odręcznie poprawkami autorskimi i redakcyjnymi. Wydruki komputerowe książek, których wydawcą jest przede wszystkim Kaliskie Towarzystwo Przyjaciół Nauk to kolejny zespół dokumentów posiadających cechy rękopisu, czyli odręczne notatki odautorskie lub korektowe.

\section{Maszynopis Jana Muszkowskiego}

Kopia maszynopisu Jana Muszkowskiego pt. „Pierwszy etap wyższych studiów bibliotekarskich UŁ (1945/46 - 1951/52)" wpłynęła do Książnicy Pedagogicznej w 1991 r., jako jeden pośród trzech dokumentów, które rozpoczęły kolekcję rękopisów. 30 kwietnia tego roku do księgi inwentarzowej został wpisany pierwszy zakupiony dokument, XIX-wieczny polsko-łaciński rękopis pt. „O systemach religijnych pogańskich w najodleglejszej starożytności” Franciszka Reuttowicza (Mszczonów 1855-1864, 202 k.). Kolejne dwa dokumenty to maszynopisy: „Kronika miasta Kalisza” Władysława Kościelniaka i Krzysztofa Walczaka (Kalisz 1983) oraz wspomniany wyżej „Pierwszy etap wyższych studiów bibliotekarskich...” J. Muszkowskiego trafiły do zbiorów jako dary. Maszynopis prof. Muszkowskiego przekazał w darze Krzysztof Walczak - dyrektor

\footnotetext{
${ }^{1}$ Stan na koniec 2013 r.
} 


\section{R.3}

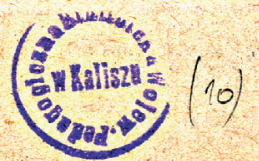

P 1 e $r$ w z y e t a p

wyższych studiów bibliotekarskich Uz.

$$
(1945 / 46-1951 / 52)
$$

Pośród licznych zaobyczy - politycznych.gospodarczych.kulturalnych - które dała narodowi Polska Rzecz pospolita ludowa,jedno z miejse, skromnych wprawdzie lecz nie ostatnich,zajmuje faktycane powolanie do zye cla odrębnej grupy zawodowej bibliotekarzy.Zawód ten bowlen istnial juz w Polsce od dawn, Preprezentowany oficjalnie przez lukasza Górnickiego od 1559 roku. ale grupa zawodowa, utworzona w malenkim gronie w Warszawie podezas pierwszej wojny światowej.pasozytowaza przez parq đziesig̨tków lat na zespolach pracowników naukowych z jednej strony. działaczy oswiatowo-kulturalnych z drugiej.Słaba organizacja, lekcewasona przez wkadze a niedoceniana przez spozeczeństwo docierała z trudem do liczby około pięcluset członków na całym obszarze Rzeczygospolitej.Nie mogło być lthaczej.skoro 
Książnicy Pedagogicznej (funkcjonującej wówczas pod nazwą Pedagogicznej Biblioteki Wojewódzkiej). Maszynopis prof. Muszkowskiego wpisany został do księgi inwentarzowej pod numerem trzecim z datą 18 września. Maszynopis liczy 18 kart formatu $21 \times 15 \mathrm{~cm}$, na których autor wprowadził poprawki maszynowo (są to poprawki pisane przez kalkę, jak i dopisywane bezpośrednio na maszynie) i drobniejsze (np. przecinki) zaznaczane ręcznie.

\section{Znaczenie artykułu Muszkowskiego i jego miejsce w dorobku autora}

O Muszkowskim napisano, iż był jednym z najwybitniejszych bibliotekarzy polskich, niestrudzonym działaczem oświatowym, bibliotekoznawcą, publicystą, literatem i doskonałym znawcą księgarstwa, a jego działalność w zakresie kształcenia bibliotekarzy miała charakter pionierski². I właśnie działaniom związanym z kształceniem bibliotekarzy przyjrzymy się trochę bliżej.

W roku 1916/1917 Muszkowski rozpoczął wykłady z bibliotekarstwa na kursach naukowych zorganizowanych z inicjatywy Wydziału Historii Książnic i Wiedzy Bibliotecznej, później - w latach 1926-1938 - systematyczny kurs dla bibliotekarzy prowadził na Wolnej Wszechnicy Polskiej.

Już wówczas myślał, by całokształt zagadnień związanych z nauką o książce wprowadzić do programów wyższych studiów akademickich. Niestety, planów tych nie udało mu się urzeczywistnić. Wrócił do nich po zakończeniu II wojny światowej. Zaangażował się w organizację nowo powstałego w 1945 r. Uniwersytetu Łódzkiego, utworzył tam autonomiczne studia bibliotekoznawcze. O jego działaniach Irena Morsztynkiewiczowa napisała:

Z całą młodzieńczą wprost energią zabrał się w 1945 roku (miał wówczas 63 lata) do wcielania jej [idei] w życie, mimo piętrzących się trudności i kosztem ogromnych wysiłków. W świeżo utworzonym po wojnie Uniwersytecie Łódzkim, który hołdował wówczas tradycjom Wolnej Wszechnicy Polskiej, zorganizował Profesor Katedrę i Zakład Bibliotekoznawstwa, zdobywając pełne prawa obywatelstwa akademickiego dla nowej, niedostrzeganej dotąd, dyscypliny naukowej ${ }^{3}$.

Dzieło było pionierskie i Muszkowski borykał się z dużymi trudności. Kilka razy zatem zmieniał koncepcję i programy studiów, by przystosować je do

${ }^{2}$ J. Muszkowski [online], [dostęp: 03.04.2013]. Dostępny w World Wide Web: http://pl.org/ wiki/Jan_Muszkowski; B. Koc, Prof. Jan Muszkowski. Wspomnienie pośmiertne. „Życie Szkoły Wyższej” 1953, nr 3, s. 144-145.

3 I. Morsztynkiewiczowa, Życie książki - Jan Muszkowski, w: Twórcy nowoczesnego bibliotekarstwa polskiego. Wrocław 1974, s. 249-250. 
wymagań stawianych przez Ministerstwo, władze akademickie oraz zmieniające się systemy szkolnictwa uniwersyteckiego, co miało miejsce w pierwszych powojennych latach. Początkowo studia zaplanowano jako czteroletnie, ale już w 1949 r. była tylko specjalizacja bibliotekarska na filologii i historii. W latach 1952-1954 organizację studiów zmieniono na dwustopniową: trzyletnie I stopnia, zakończone dyplomem zawodowym i II stopnia - dwuletnie studia magisterskie.

Pomimo ciaggłych zmian, reorganizacji i szczupłej kadry dydaktycznej do 1953 r. studia w Katedrze Bibliotekoznawstwa, którą kierował profesor Muszkowski ukończyło 36 absolwentów z dyplomem zawodowym I stopnia i 35 magistrów. Ponadto Muszkowski na Uniwersytecie Łódzkim przeprowadził w 1948 r. przewód habilitacyjny Adama Łysakowskiego z bibliotekoznawstwa, a w 1952 r. doktorat Karola Głombiowskiego, pierwszy w tej dziedzinie ${ }^{4}$.

Kwestie dotyczące studiów bibliotekoznawczych Muszkowki podjął na łamach prasy fachowej już w 1945 r., w „Bibliotekarzu” opublikował tekst pt. Ksztatcenie bibliotekarzy (nr 2/3), który ukazał się także w osobnej odbitce (1946). Autor przypomniał w artykule, że dopiero wiek XIX zapoczątkował „wyodrębnienie pewnych grup przedmiotów [...] dla określonego celu kształcenia bibliotekarzy, stwarzając podstawy tego zawodu"; powstała wówczas Ecole des Chartes w Paryżu (1821), dająca m.in. prawo do pracy w bibliotekach. W II połowie wieku XIX egzaminy dla bibliotekarzy wprowadzono w Anglii (1860), we Francji (1879, we Włoszech oraz w Niemczech (1864); powstała pierwsza uniwersytecka katedra bibliotekoznawstwa (Getynga 1886) i szkoła bibliotekarska (New York 1887). Profesor podkreślał zmianę roli bibliotekarza XIX i XX wieku, pisał, że tworzenie bibliotek oświatowych w różnych krajach doprowadziło do kształcenia bibliotekarzy. Zastanawiał się nad systemami kształcenia bibliotekarzy, czy powinny być to systemy odmienne dla różnych typów bibliotek, czy jeden system posiadający różne poziomy. Odwołując się do systemów szkolenia w Stanach Zjednoczonych i Europie Muszkowski skupił się na systemie szkolenia bibliotekarzy w Polsce. Egzaminy dla bibliotekarzy wprowadziło rozporządzenie z 1930 r., miały one jednak charakter praktyczny a nie naukowy. Bibliotekarzowi - według Muszkowskiego - potrzebny jest zasób wiedzy specjalistycznej, związanej z wytwarzaniem dokumentów, ich obiegiem i konsumpcją, czyli nauka o książce „niezbędna w przygotowaniu bibliotekarzy do wykonywania zawodu”. W okresie międzywojennym przygotowanie na poziomie akademickim zapewniała Wolna Wszechnica Polska w Warszawie (Studium Pracy Społeczno-Oświatowej), a po II wojnie świa-

\footnotetext{
${ }^{4}$ Tamże, s. 250.
} 
towej utworzona w ramach Wydziału Humanistycznego UŁ Katedra Księgoznawstwa i Bibliotekarstwa, która w końcowym efekcie miała działać jako Studium Bibliotekarskie i szkolić bibliotekarzy różnych typów bibliotek oraz prowadzić przysposobienie biblioteczne studentów UŁ. Muszkowski przedstawił też program Studium.

W 1948 r. w „Bibliotekarzu” ukazały się również kolejne artykuły Muszkowskiego, były to Nauka o ksiązce (nr 6/7), w którym profesor przedstawił konspekt wykładów na Uniwersytecie Łódzkim oraz nawiązujący do niego Ksiązka jako przedmiot nauki (nr 10/11), stanowiący częściowy przedruk z artykułu ogłoszonego w 1945 r. na łamach „Książki i Kultury” (Rodowód książki, nr 1).

Redakcja „Bibliotekarza” w 1948 r., z inicjatywy prof. Muszkowskiego, wprowadziła dział „Materiały do kształcenia pracowników książki” (nie tylko bibliotekarzy), prezentujący materiały dotyczące programu i metod kształcenia pracowników książki w szerokim ujęciu (także sprawozdania z kursów bibliotekarskich i księgarskich)5. Muszkowski ogłosił tu: Tematy prac seminaryjnych, magisterskich $i$ doktorskich proponowane do wykonania w Zaktadzie Bibliotekoznawstwa U.E. (nr 10/11) oraz Przeglad prac kandydackich $i$ doktorskich $z$ zakresu bibliotekoznawstwa i bibliografii w Zwiazku Radzieckim w latach 19381946 (nr 12).

Rok 1949 przyniósł Nowe prady w ksztatceniu bibliotekarzy (nr 1/2), referat pod tym tytułem wygłosił profesor 13 grudnia 1948 r. na konferencji, zorganizowanej przez Państwowy Instytut Książki w Łodzi, poświęconej szkolnictwu bibliotekarskiemu i księgarskiemu. W artykule Muszkowski dokonał przeglądu kształcenia bibliotekarzy na przykładzie Francji, Wielkiej Brytanii, Stanów Zjednoczonych, Czechosłowacji oraz Związku Radzieckiego dochodząc do wniosku, że widoczna jest tendencja do kształcenia dwustopniowego z podziałem na typy bibliotek (naukowe i powszechne) lub funkcji wykonywanych w bibliotece (kierownicze, średnie i niższe). W Polsce natomiast zaczął się kształtować system kształcenia trzystopniowego (czteroletnia szkoła zawodowa o typie licealnym, jedno- lub dwuletnia szkoła specjalna dla kandydatów do średniej służby w bibliotekach naukowych i większych powszechnych, studia uniwersyteckie).

W związku z nowelizacją przepisów z 1926 r. dotyczącą programów studiów i egzaminów na stopień magistra filozofii w zakresie filologii polskiej i historii w artykule, czy raczej komentarzu, Pierwsze polskie przepisy studiów bibliotekarkkich na poziomie uniwersyteckim („Bibliotekarz” 1949, nr 7/8) Muszkowski przypomniał koncepcję programu studiów i egzaminów w zakresie biblioteko-

\footnotetext{
5 „Bibliotekarz” 1948, nr 10/11, s. 163.
} 


\section{Pierwszy etap wyższych studiów bibliotekarskich UŁ $(1945 / 46-1951 / 52)$}

Posród licznych zdobyczy - politycznych, gospodarczych, kulturalnych - które dala narodowi Polska Rzeczpospolita Ludowa, jedno z miejsc, skromnych wprawdzie lecz nie ostatnich, zajmuje faktyczne po= wołanie do życia odrebnej grupy zawodowej bibliotekarzy. Zawód ten bowiem istnial już w Polsce od dawna, reprezentowany oficjalnie przez Lukasza Górnickiego od 1559 roku, ale grupa zawodowa, utworzona w maleńkim gronie w Warszawie podezas pierwszej wojny światowej, pasożytowała przez parę dziesiątków lat na zespołach pracowników naukowych z jednej strony, działaczy oświatowo-kulturalnych $z$ drugiej. Słaba organizacja, lekceważona przez władze a niedoceniana przez społeczeństwo, docierała z trudem do liczby okolo pieciuset czlonków na calym obszarze Rzeczpospolitej. Nie mogło byé inaczej, skoro jedyny urzędowy cenzus zawodowy stanowilo swiadectwo egzaminu pierwszej lub drugiej kategorii w służbie bibliotekarskiej, dostępne wyłącznie dla pracowników zatrudnlonych już faktycznie w jednej z bibliotek państwowych, gdy przeważająca większośc bibliotekarzy pracowala $\mathrm{w}$ instytucjach niepaństwowych. Pracownicy bibliotek fundacyjnych, miejskich samorządowych, szkolnych, spolecznych i prywatnych rekrutowali się spomiędzy osób nie posiadających żadnego przygotowania zawodowego lub przeszkolonych prowizorycznie i przeważnie niedostatecznie na doraźnych kưrsach rozmaitej długości, prowadzonych po amatorsku, bez ustalonych wytycznych programowych $i$ dydaktycznych. Próby ksztsłcenia zawodowego podejmowane przez Wolną Wszechnice Polska, -przez Biblioteke Publiczna m. st. Warszawy, przez Szkole Pracownic Spolecznych, którym przysługuje zaszczytna odznaka pionierstwa, nie mogły zaspokoic wszyst-kich potrzeb i zachowaly charakter wysilkbw odosobnionych*).

- Por. Ksztalcenie bibliotekarzy na Studium Pracy Społeczno-Oświatowej Wydzłału Pedagogieznego WWP. W-wa 1936 --Drukowane konspekty Szkoty Bibl. Publ. $m$. st. Warszawy.

\section{0}

Rząd Polski Ludowej stworzyl najpierw teren dla masowej pracy" bibliotekarskiej droga realizacji dekretu o siecl bibliotecznej z 17 kwietnia 1946 r., nasteppnie zaś zapoczątkowal systematyczne szkolenie bibliotekarzy na różnych poziomach, poczawszy od doraźnych kursow w. osrodku Jarocińskim, poprzez licea czteroletnie dla mlodzieźy $\mathrm{i}$ dwuletnie dla dorosłych, aż do studiów uniwersyteckich. Jest to jeszcze, jak w wielu innych dziedzinach kultury i szkolníctwa, okres prób $i$ eksperymentów, którym brak jednolitości i konsekwencji wewnętrznej pod względem programowym i dydaktycznym. Niemniej jednak początek zostal zrobiony i nagromadzono pewien material doswiadczalny domagający się analizy i oceny. Zwłaszcza ulokowanie trzech ośrodków dyspozycyjnych bibliotekarstwa $w$ trzech różnych resortach domaga się wymiany doświadczeń, osiągniętych na różnych odcinkach pracy szkoleniowej, i publicznej nad nimi dyskusji. Pragnąlbym w rozważaniach poniższych zapoczątkować tẹ dyskusję omówieniem pierwszego zamkniętego níedawno etapu działalności jednego $\mathrm{z}$ ośrodków uniwersyteckich.

W dniu 22 marca 1945 roku, kiedy na froncie zachodnim toczyły się jeszcze ostre, walki, rozpoczęto wykłady na nowootworzonej w Eodzi wyższej uczelni państwowej, która nie posiadała jeszcze wówczas nawet nazwy zatwierdzonej ostatecznie przez władze. Dopiero 24 maja zapadła formalna uchwala o utworzeñlu Uniwersytetu Łódzkiego, zaś zarządzenie Ministra Oswiaty z 11 lutego 1946 r. powolało do życia - miẹdzy innymi równieź $I$ katedrę bibliotekoznawstwa (Dz. U. Min. OŚw. Nr 3 z 31. v. 1946 poz. 69). W dniu 12 ' czerwca tegoż roku podpisana została przez Prezydenta Rzeczypospolitej nominacja na stanowisko profesora zwyczajnego tego przedmiotu. Bylo to usankcjonowanie stanu faktycznego istniejacego już przeszlo od roku.

Poczatkowo projektowano zorganizowanie odrębnege wydziału pracy kulturalnej. na którym-miała byc czynna ta katedra I w ramach którego istotnie

Fragment artykułu J. Muszkowskiego Pierwszy etap wyższych studiów bibliotekarskich UE (1945/46 - 1951/52). „Bibliotekarz” 1953, nr 1.

znawstwa i nauki o książce, na stopień magistra filozofii uchwalonego przez Radę Wydziału Humanistycznego w Łodzi (czerwiec 1946), ale odrzuconego przez Sekcję Humanistyczną Rady Głównej Nauki i Szkół Wyższych (maj $1948)^{6}$.

Poza tym prof. Muszkowski opracował skrypt Nauka o książce. Skrypt z wyktadów. R. akad. 1947/48. Cz. 1, Powstawanie książki (rozdz. 1-3, Łódź 1948)

${ }^{6}$ „Bibliotekarz” opublikował także pełny tekst Rozporządzenia Ministra W.R.i O.P. z dnia 2 kwietnia 1926 r. w sprawie programu studiów i egzaminów w zakresie historii, na stopień magistra filozofii, uzupełnionego przez Zarządzenie Ministra Oświaty z dn. 1 lutego w sprawie specjalizacji bibliotekoznawczej. 
i drugą edycję pod tym samym tytułem na rok akademicki 1948/49, obejmującą trzy kolejne rozdziały (rozdz. 4-6) Powstawania książki (Łódź 1949). Na temat kształcenia kadr bibliotekarzy naukowych zabrał głos w dyskusji w czasie posiedzenia zamykającego obrady Konferencji Krynickiej w lutym $1951 \mathrm{r}$. („Przegląd Biblioteczny” 1951, z. 3/4).

W ostatnim, opublikowanym po śmierci autora, artykule, pt. Pierwszy etap wyższych studiów bibliotekarskich UE (1945/46-1951/52) Muszkowski pisał, że bibliotekarze uznani zostali za odrębną grupę zawodową, a dekret o bibliotekach z 17 kwietnia 1946 r. dał podstawy do masowej pracy bibliotekarskiej i zapoczątkował szkolenie bibliotekarzy na różnych poziomach (kursy w Jarocinie, licea czteroletnie dla młodzieży i dwuletnie dla dorosłych, studia uniwersyteckie). Choć miał świadomość, że szkolenie bibliotekarzy to jeszcze okres prób i eksperymentów, to według niego rozpoczęte w tym zakresie działania wymagały analizy i oceny. Uważał, że publicznej dyskusji należy poddać fakt rozmieszczenia trzech ośrodków dyspozycyjnych bibliotekarstwa w trzech różnych resortach. Uważał także, że dyskusję należy rozpocząć od omówienia działalności jednego z ośrodków uniwersyteckich, czyli katedry bibliotekoznawstwa UŁ, w której zakończył się pierwszy zamknięty etap działalności. Pisał więc o organizacji i programie studiów, omawiając problemy w tym zakresie od początku istnienia łódzkiego ośrodka kształcenia bibliotekarzy.

Przypomniał przyjęty przez Radę Wydziału i odrzucony przez Ministerstwo Oświaty projekt organizacji i programu studiów, prowadzenie studiów do 1949 r. bez zatwierdzonego i zmienianego kilkakrotnie programu w warunkach niepewności i braku gwarancji ukończenia studiów i uzyskania stopni naukowych. Pisał profesor o staraniach zmierzających do umocnienia studium bibliotekarskiego, czyli opracowywaniu kolejnych projektów programów (1946, 1948), uwzględniających zmiany i poprawki innych uniwersytetów, dyskusjach w Sekcji Humanistycznej Rady Głównej (1948) i w końcowym efekcie uzyskaniu koncepcji programu magisterium z bibliotekoznawstwa jako specjalizacji przy trzech kierunkach humanistyki. W 1948 r. uzyskano zgodę na wprowadzenie specjalizacji z bibliotekoznawstwa $\mathrm{w}$ ramach magisterium z filologii polskiej i historii.

Projekt specjalizacji bibliotekarskiej przy kierunku historii i filologii polskiej uzyskał akceptację Ministerstwa Oświaty, wynikały z niego jednak zmiany związane z dodatkowymi egzaminami dla studentów (uzupełnianie studiów i egzaminów w zakresie kierunku głównego), co wymagało czasu.

Profesor odnotował także w artykule rezolucję w sprawie szkolnictwa bibliotekarskiego oraz księgarskiego podjętą na konferencji, zorganizowanej w grudniu 1948 r. przez Państwowy Instytut Książki. 
Bardzo trafnie artykuł Muszkowskiego Pierwszy etap wyższych studiów bibliotekarskich UE (1945/46-1951/52) podsumowała Redakcja „Bibliotekarza” pisząc, że pokazuje ,jak do ostatnich niemal chwil Swego pracowitego życia walczył On o podniesienie poziomu zawodu bibliotekarskiego, o należyte przygotowanie bibliotekarzy do ich doniosłych zadań społecznych"7.

Przegląd dorobku piśmienniczego Muszkowskiego pokazuje, że po II wojnie światowej na kwestie kształcenia bibliotekarzy profesor kładł szczególny nacisk, co potwierdza, nieprzeznaczony pierwotnie do druku (omówiony wyżej) artykuł Pierwszy etap wyższych studiów bibliotekarskich...

Z opublikowanej w 1972 r. w "Studiach o Książce” bibliografii prac ${ }^{8}$, obejmującej 345 pozycji z lat 1902-1960 wynika, że początkowo zainteresowania profesora koncentrowały się wokół literatury. Zajmował się także publicystyką, ogłaszając swoje teksty na łamach wielu czasopism. Na potrzeby Wielkiej encyklopedii powszechnej ilustrowanej opracował wiele biogramów niemieckich pisarzy-prozaików, poetów i dramaturgów. Zajmował się także publicystyką, artykuły, recenzje (teatralne), krytykę literacką, komentarze publikował na łamach „Społeczeństwa” - tygodnika naukowoliterackiego, społecznego i politycznego oraz innych czasopism - „Widnokrąg”, „Tydzień”, „Myśl Polska”, „Kuźnia”, „Wiedza”, „Izraelita”.

Praca w bibliotekach zaowocowała publikacjami dotyczącymi bibliotekarstwa, bibliografii i czytelnictwa. Na łamach prasy fachowej, i nie tylko, wypowiadał się na temat przeszłości i teraźniejszości w życiu bibliotek (1929), egzemplarza obowiązkowego $(1927,1930)$, pisał o społecznej roli pracy bibliotekarskiej (1934), bibliotekach naukowych $(1930,1931)$ i oświatowych $(1933$, 1935), ustawie bibliotecznej (1934). Wydawał wykłady z zakresu bibliotekoznawstwa i bibliografii dla kursów bibliotekarskich, publikował artykuły dotyczące kształcenia bibliotekarzy (wymienione wyżej).

Szereg artykułów poświęcił książce, m. in. sprawom jej wytwarzania i obiegu (1927), wystawom $(1925,1926,1931)$, pisał o kwestiach wydawniczych $(1915,1922)$ oraz o wrogach i miłośnikach książki (1922-23). W 1936 r. wydał Życie ksiażki (wyd. 2 - 1951).

Pierwszy artykuł na temat bibliografii, a właściwie jej potrzeb ogłosił Muszkowski w 1915 r. W kolejnych latach pisał o katedrze bibliografii w Szkole Głównej Warszawskiej (1918), bibliografii polskiej 1900-1925 (1918, 1925, 1936), Karolu Estreicherze (1927, 1928) i jego Bibliografii Polskiej (1929,

7 „Bibliotekarz” 1953, nr 1, s. 13.

${ }^{8}$ I. Treichel z udziałem H. Tadeusiewicz, Bibliografia prac Jana Muszkowskiego. „Studia o Książce" T. 3, 1972, s. 55-84, obejmuje także spis prac o J. Muszkowskim. 
1930) czy Polskim Instytucie Bibliograficznym $(1928,1929)$, a także statystyce druków $(1926,1931)$, rejestracji produkcji wydawniczej (1948).

Obszarem zainteresowań Muszkowskiego było także księgarstwo. Tematy księgarskie omawiał w „Przeglądzie Księgarskim” (był jego redaktorem w latach 1930-1932), pisał na temat historii księgarstwa polskiego, opublikował artykuły dotyczące działalności Jakuba Mortkowicza (1928), E. Wendego i Spółki (1928), firmy M. Arcta (1937), często poruszał kwestie zawodowego wykształcenia księgarskiego $(1927,1928,1929,1930)$ oraz sprawy bieżące. Opracował monografię firmy Gebethnera i Wolffa (1938), przygotował biogramy księgarzy i wydawców do Polskiego Stownika Biograficznego (Feliks Jan Gebethner, Gustaw Adolf Gebethner, Jan Robert Gebethner, Tadeusz Jerzy Gebethner, Władysław Ludwik Gubrynowicz, Leon Gajec).

\section{Edycja artykułu i jej porównanie z maszynopisem}

Praca Muszkowskiego opublikowana została krótko po jego śmierci (zm. 29 I 1953 r.) na łamach pierwszego numeru (styczeń-luty) „Bibliotekarza”

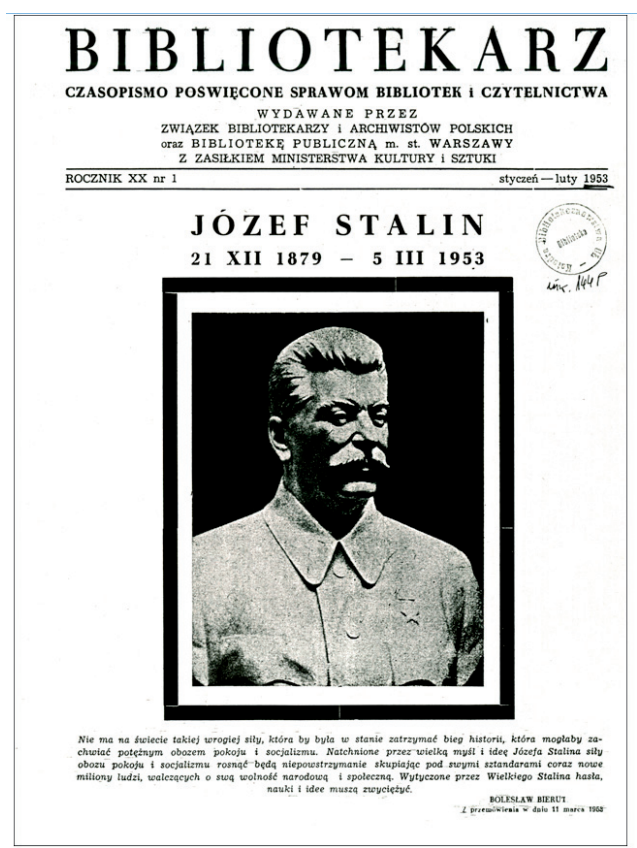

„Bibliotekarz” 1953 nr 1 - okładka z 1953 r. - czasopisma poświęconego sprawom bibliotek i czytelnictwa, czyli periodyku, w którym swoje artykuły ogłaszał już od 1945 r. Choć w nocie od redakcji czytamy, że autor nie przeznaczał tekstu do druku, miał go wygłosić na konferencji w sprawie szkolenia bibliotekarzy, na którą miał wyjechać. Chodziło o konferencję w Jarocinie, a referat miał wygłosić na zlecenie Centralnego Zarządu Bibliotek ${ }^{10}$. Poruszane przez Muszkowskiego sprawy redakcja „Bibliotekarza” uznała jednak za bardzo ważne, skoro artykuł nie został odłożony, a ogłoszony w pierwszym numerze, jaki wyszedł po śmierci profesora.

\footnotetext{
9 „Bibliotekarz” 1953, nr 1, s. 13.

${ }^{10}$ H. Więckowska, Jan Muszkowski uczony - bibliolog. „Przegląd Biblioteczny” 1953, z. 2, s. 97.
} 
Głos profesora w kwestii programu studiów bibliotekarskich ukazał się w momencie żałoby po śmierci Józefa Stalina. Na okładce numeru „Bibliotekarza”, w którym znalazł się artykuł Muszkowskiego zamieszczono portret Stalina.

Porównując maszynopis z opublikowanym w „Bibliotekarzu” artykułem trzeba stwierdzić, że redakcja tylko w nielicznych przypadkach ingerowała w tekst. Sformułowanie Muszkowskiego: „praktykę w bibliotece wzgl. w księgarni” (maszynopis k. 6) zmieniono na: „praktykę w bibliotece lub w księgarni”. Zastosowane przez Muszkowskiego dwa podkreślenia (maszynopis k. 13) zamieniono na kursywę, a słowo „siedmioletni studenci” zamieniono na „siedmioroczni studenci”, chodziło bowiem o studentów mających już za sobą siedem lat studiowania.

W jednym przypadku redakcja zmieniła słowo „filologicznym” na „filozoficznym”; Muszkowski pisał (maszynopis k. 11): „... lecz jedynie specjalizację przy kierunkach: historycznym, filologicznym i socjologicznym...”, wydaje się więc, że chodziło o kierunek filologiczny a nie filozoficzny.

W maszynopisie (k. 10-11) czytamy: „W dniu 7 maja tegoż roku [1948] odbyło się posiedzenie Sekcji Humanistycznej R. G., na którym miał być dyskutowany nowy projekt programu, zaaprobowany w zasadzie przez jednomyślną niemal opinię uniwersytetów polskich i przepracowany w Departamencie IV Min. Oświaty...”. W tym przypadku redakcja „Bibliotekarza” wprowadziła poprawkę dotyczącą dat posiedzeń, które odbyły się w dniach 11 i 14 maja, rozwiązała skrót R. G. [Rady Głównej] oraz wykreśliła literę i, zamiast niej wstawiając przecinek.

Redakcja wprowadziła też korektę w zapisie: „... stały się przedmiotem rozważania władz wyższych i Wydziału Prawnego Ministerstwa Oświaty...” na: „stał się [projekt] przedmiotem rozważania Ministerstwa Oświaty...”.

Opublikowanie referatu profesora, w niezmienionej niemal wersji, świadczy z jednej strony o dobrym piórze autora, z drugiej zaś o szacunku redakcji dla tekstu Muszkowskiego.

\section{Podsumowanie}

Dwadzieścia lat pracy w bibliotekach (X 1915-1935) pozwoliło Muszkowskiemu poznać zasady i organizację pracy bibliotecznej oraz potrzeby tego środowiska, przede wszystkim jednak umożliwiło mu podjęcie działań związanych z zarysowaniem programu mającego na celu podniesienie poziomu wykształcenia fachowego i umocnienia pozycji zawodowej bibliotekarzy ${ }^{11}$. Po objęciu

\footnotetext{
${ }^{11}$ M. Mlekicka, Muszkowski jako bibliotekarz. „Studia o Książce” T. 3, 1972, s. 187.
} 
w 1945 r. kierownictwa katedry bibliotekoznawstwa profesor Muszkowski skupił się na koncepcji opracowania projektu organizacji i planu studiów bibliotekoznawczych w programach uniwersyteckich, koncepcji przystosowanej do potrzeb i warunków, co przedstawił w referacie (1953), którego autorski maszynopis zachował się do dziś.

\section{Abstract \\ The transcript of the Jan Muszkowski's last work in the collection of Książnica Pedagogiczna im. A. Parczewskiego in Kalisz}

In the article the author presents the typescript of the last work written by Jan Muszkowski in 1953. The analysed article, titled Pierwszy etap wyższych studiów bibliotekarskich UŁ (1945/46-1951/52), is currently collected by Książnica Pedagogiczna im. A. Parczewskiego in Kalisz. 